\title{
Luminescence Quenching and Photooxidation of Trichlorostannate(II) by Oxygen
}

\author{
Alexander Becht, Arnd Vogler* \\ Institut für Anorganische Chemie, Universität Regensburg, D-93040 Regensburg \\ Z. Naturforsch. 49b, 778-780 (1994); received February 14, 1994 \\ Tin(II), Chloro Complexes, Luminescence Quenching, Photooxidation \\ The luminescence of $\left[\mathrm{SnCl}_{3}\right]^{-}$in acetonitrile $(\tau=1.6 \mu \mathrm{s})$ is quenched by oxygen with $\mathrm{k}=$ \\ $3.8 \times 10^{8} \mathrm{~L} \mathrm{~mol}^{-1} \mathrm{~s}^{-1}$. This quenching is associated with an electron transfer from $\left[\mathrm{SnCl}_{3}\right]^{-}$in \\ its ${ }^{3} \mathrm{P}_{1}$ sp-excited state to $\mathrm{O}_{2}$. Secondary processes lead to the formation of $\mathrm{SnOCl}_{2}\left(\mathrm{CH}_{3} \mathrm{CN}\right)_{n}$ \\ with an overall quantum yield of $\varphi=1.5$ at $\lambda_{\text {irr }}=254 \mathrm{~nm}$. While this Sn(IV) complex is not \\ light sensitive, $\left[\mathrm{SnCl}_{6}\right]^{2-}$ in $\mathrm{CH}_{3} \mathrm{CN}$ undergoes a photochemical reductive elimination with \\ the generation of $\left[\mathrm{SnCl}_{3}\right]^{-}$with $\varphi=0.015$ at $\lambda_{\text {irr }}=254 \mathrm{~nm}$.
}

\section{Introduction}

It has been known for sixty years that tin(II) chloro complexes in aqueous solution undergo a photooxidation in the presence of oxygen [1]. These studies have revealed some of the details of the reaction mechanism. The photooxidation of tin(II) has found interesting applications. It is utilized for the generation of metallic images in the electronics industry [2]. Nevertheless, some basic features of this photooxidation are not yet understood. The reactive excited state and the primary photochemical step were not characterized in previous studies. Relevant observations are now reported and discussed. The present investigation was facilitated by our related work on the photooxidation of other $\mathrm{s}^{2}$ metal ions [3] such as $\mathrm{Sb}^{3+}$ [4], $\mathrm{Tl}^{+}[5]$, and $\mathrm{Pb}^{2+}$ [6]. These studies did not only reveal the initial events in the photooxidation, but it was also shown that these photooxidations can be reversed by a subsequent reductive photoelimination of the photooxidized products. The photolysis of complexes of $\mathrm{s}^{0}$ ions such as $\mathrm{Sb}^{5+}, \mathrm{Tl}^{3+}$, and $\mathrm{Pb}^{4+}$ may thus lead to the regeneration of the corresponding $\mathrm{s}^{2}$ ions. In the present work this possibility was also explored for $\mathrm{Sn}^{4+}$.

\section{Experimental}

Materials. The compounds $\left(\mathrm{NEt}_{4}\right)\left[\mathrm{SnCl}_{3}\right]$ [7] and $\left(\mathrm{NEt}_{4}\right)_{2}\left[\mathrm{SnCl}_{6}\right]$ [8] were prepared according

* Reprint requests to Prof. Dr. A. Vogler.

0932-0776/94/0600-0778 \$06.00

(C) Verlag der Zeitschrift für Naturforschung,

D-72072 Tübingen to published procedures. Acetonitrile was spectrograde.

Spectroscopy. Absorption spectra were recorded with a Uvikon 860 double-beam spectrophotometer. Emission spectra were obtained on a Hitachi 850 spectrofluorimeter which was equipped with a Hamamatsu 928 photomultiplier. The luminescence spectra were corrected for monochromator and photomultiplier efficiency variations. Absolute emission quantum yields were determined by comparison of integrated emission intensities of $\left[\mathrm{SnCl}_{3}\right]^{-}$with that of quinine sulphate in $0.5 \mathrm{M}$ $\mathrm{H}_{2} \mathrm{SO}_{4}\left(\lambda_{\max }=452 \mathrm{~nm} ; \varphi=0.546\right)$ [9] under identical conditions of excitation wavelength, optical density, and apparatus parameters.

Photolyses. The photolyses were carried out at room temperature in $1-\mathrm{cm}$ spectrophotometer cells. The light source was a Hanovia $\mathrm{Xe} / \mathrm{Hg} 977$ B-1 $(1000 \mathrm{~W})$ lamp. Monochromatic light $\left(\lambda_{\text {irr }}=\right.$ $254 \mathrm{~nm}$ ) was obtained by means of a Schoeffel GM 250-1 high-intensity monochromator. For quantum yield determinations the complex concentrations were such as to have essentially complete light absorption. The total amount of photolysis was limited to less than $5 \%$ to avoid light absorption by the photoproduct. Absorbed light intensities were determined by a Polytec pyroelectric radiometer which was calibrated and equipped with an RkP345 detector.

Analyses. Peroxide was identified using the peroxide test of Merck (Merckoquant 10011). Chlorine was detected following a published procedure [10].

\section{Results}

All experiments were carried out in acetonitrile solutions. Owing to complicated equilibria of various tin(II) chloro complexes in aqueous solutions [11] water is less suitable as a solvent. The salt 
$\left(\mathrm{NEt}_{4}\right)\left[\mathrm{SnCl}_{3}\right]$ was dissolved in acetonitrile without decomposition. The complex ion $\left[\mathrm{SnCl}_{3}\right]^{-}$in argon-saturated $\mathrm{CH}_{3} \mathrm{CN}$ showed a green luminescence with $\lambda_{\max }=510 \mathrm{~nm}\left(\lambda_{\mathrm{exc}}=250 \mathrm{~nm}\right), \varphi=$ 0.07 [12] and $\tau=1.6 \mu \mathrm{s}$. In air-saturated acetonitrile $\left(\left[\mathrm{O}_{2}\right]=2.2 \times 10^{-3} \mathrm{M}\right)$ [13] the emission quantum yield dropped to $\varphi=0.03$.

While in argon-saturated acetonitrile $\left[\mathrm{SnCl}_{3}\right]^{-}$ was not light-sensitive, an efficient photolysis took place in the presence of oxygen. The irradiation was accompanied by the disappearance of the green luminescence and by changes in the absorption spectrum (Fig. 1). The decrease of the concentration of $\left[\mathrm{SnCl}_{3}\right]^{-}$was determined by measuring the absorbance decrease at $\lambda=292 \mathrm{~nm}$. The anion $\left[\mathrm{SnCl}_{3}\right]^{-}$disappeared with a quantum yield of $\varphi=$ 1.5 at $\lambda_{\text {irr }}=254 \mathrm{~nm}$. Small amounts of peroxide $\left(\sim 10^{-5} \mathrm{M}\right)$ were detected in the photolyzed solution of $\left[\mathrm{SnCl}_{3}\right]^{-}\left(1.68 \times 10^{-4} \mathrm{M}\right)$. The same spectral changes which took place during the photolysis of $\left[\mathrm{SnCl}_{3}\right]^{-}$in acetonitrile (Fig. 1) were also observed when these solutions were exposed to air in the dark. However, the thermal reaction was much slower.

Messin et al. identified the tin(IV) complex $\mathrm{SnOCl}_{2}\left(\mathrm{CH}_{3} \mathrm{CN}\right)_{n}$ with $n=1-2$ as the product of the thermal autoxidation of $\mathrm{SnCl}_{2}$ in $\mathrm{CH}_{3} \mathrm{CN}$ [14]. It is concluded that $\mathrm{SnOCl}_{2}\left(\mathrm{CH}_{3} \mathrm{CN}\right)_{n}$ was also produced in the photolysis of $\left[\mathrm{SnCl}_{3}\right]^{-}$in acetonitrile in the presence of air.

The spectral changes which took place during the photolysis of $\left[\mathrm{SnCl}_{3}\right]^{-}$in $\mathrm{CH}_{3} \mathrm{CN}$ (Fig. 1) did

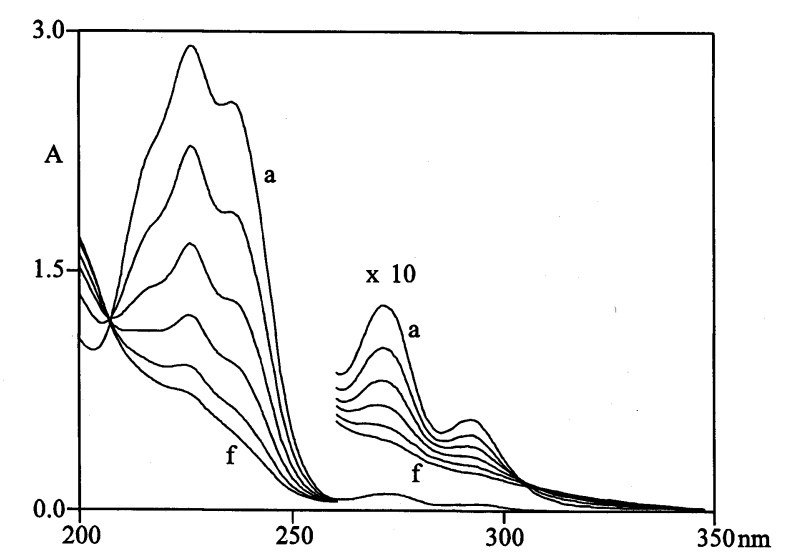

Fig. 1. Spectral changes during the photolysis of $1.68 \times 10^{-4} \mathrm{M}\left(\mathrm{NEt}_{4}\right)\left[\mathrm{SnCl}_{3}\right]$ in $\mathrm{CH}_{3} \mathrm{CN}$ at (a) $0,5,10,15$, 20 and (f) $25 \mathrm{sec}$ irradiation time $\left(\lambda_{\mathrm{irr}}=254 \mathrm{~nm}\right)$.

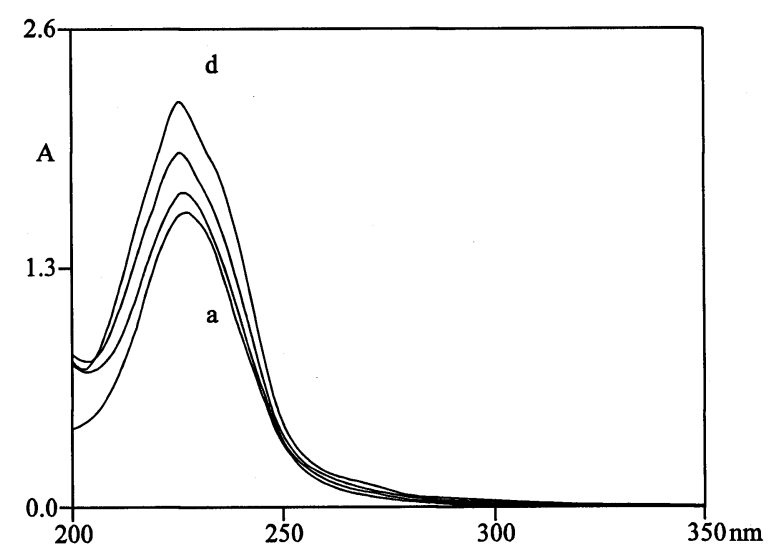

Fig. 2. Spectral changes during the photolysis of $1.37 \times 10^{-4} \mathrm{M}\left(\mathrm{NEt}_{4}\right)_{2}\left[\mathrm{SnCl}_{6}\right]$ in $\mathrm{CH}_{3} \mathrm{CN}$ at (a) $0,10,20$ and (d) $30 \mathrm{~min}$ irradiation time $\left(\lambda_{\mathrm{irr}}=254 \mathrm{~nm}\right)$.

not depend on the presence of additional chloride $\left(\sim 10^{-2} \mathrm{M}\right)$. Accordingly, under these conditions the irradiation of $\left[\mathrm{SnCl}_{3}\right]^{-}$did not yield $\left[\mathrm{SnCl}_{6}\right]^{2-}$, which has an absorption spectrum somewhat different from that of the photooxidation product.

While $\mathrm{SnOCl}_{2}\left(\mathrm{CH}_{3} \mathrm{CN}\right)_{n}$ in $\mathrm{CH}_{3} \mathrm{CN}$ was hardly light-sensitive, the complex ion $\left[\mathrm{SnCl}_{6}\right]^{2-}$ underwent a clean photoconversion to $\left[\mathrm{SnCl}_{3}\right]^{-}$in the absence of air as indicated by the concomitant spectral variations (Fig. 2). The formation of $\left[\mathrm{SnCl}_{3}\right]^{-}$was also confirmed by the appearance of its green luminescence. Chlorine was detected as a further photoproduct by qualitative analysis. The reductive elimination of $\left[\mathrm{SnCl}_{6}\right]^{2-}$ to form $\left[\mathrm{SnCl}_{3}\right]^{-}$took place with a quantum yield of $\varphi=$ 0.015 at $\lambda_{\text {irr }}=254 \mathrm{~nm}$.

In the presence of air the photolysis of $\left[\mathrm{SnCl}_{6}\right]^{2-}$ in $\mathrm{CH}_{3} \mathrm{CN}$ initially led to the formation of $\left[\mathrm{SnCl}_{3}\right]^{-}$, but at later stages $\left[\mathrm{SnCl}_{3}\right]^{-}$underwent a secondary photolysis with the formation of $\mathrm{SnOCl}_{2}\left(\mathrm{CH}_{3} \mathrm{CN}\right)_{n}$ (see above).

\section{Discussion}

The longest-wavelength absorption bands $\left(\lambda_{\max }=272\right.$ and $\left.292 \mathrm{~nm}\right)$ and the emission $\left(\lambda_{\max }=\right.$ $510 \mathrm{~nm})$ of $\left[\mathrm{SnCl}_{3}\right]^{-}$are assigned to a metal-centered $\mathrm{sp}$ transition between the ${ }^{1} \mathrm{~S}_{0}$ ground and ${ }^{3} \mathrm{P}_{1}$ excited state [12]. The emission of $\left[\mathrm{SnCl}_{3}\right]^{-}$is quenched by oxygen. Simultaneously, $\left[\mathrm{SnCl}_{3}\right]^{-}$undergoes a photooxidation. According to these observations and in analogy to other $\mathrm{s}^{2}$ complexes [3] 
the primary events of this photooxidation can be described by the following scheme:

$$
\begin{aligned}
& {\left[\mathrm{SnCl}_{3}\right]^{-}+\mathrm{h} v \rightarrow\left[\mathrm{SnCl}_{3}\right]^{-*}} \\
& {\left[\mathrm{SnCl}_{3}\right]^{-*} \stackrel{\mathrm{k}_{\mathrm{ND}}}{\longrightarrow}\left[\mathrm{SnCl}_{3}\right]^{-}+\text {heat }} \\
& \text { (non-radiative deactivation) } \\
& {\left[\mathrm{SnCl}_{3}\right]^{-*} \stackrel{\mathrm{k}_{\mathrm{L}}}{\longrightarrow}\left[\mathrm{SnCl}_{3}\right]^{-}+\mathrm{h} \nu^{\prime}} \\
& \text { (luminescence) } \\
& {\left[\mathrm{SnCl}_{3}\right]^{-}+\mathrm{O}_{2} \stackrel{\mathrm{k}_{\mathrm{ET}}}{\longrightarrow}\left[\mathrm{SnCl}_{3}\right]+\mathrm{O}_{2}^{-}}
\end{aligned}
$$

This scheme yields some simple equations:

$$
\begin{aligned}
\tau & =\frac{1}{\mathrm{k}_{\mathrm{ND}}+\mathrm{k}_{\mathrm{L}}+\mathrm{k}_{\mathrm{ET}}\left[\mathrm{O}_{2}\right]} \\
\varphi_{\mathrm{L}} & =\frac{\mathrm{k}_{\mathrm{L}}}{\mathrm{k}_{\mathrm{ND}}+\mathrm{k}_{\mathrm{L}}+\mathrm{k}_{\mathrm{ET}}\left[\mathrm{O}_{2}\right]} \\
\varphi_{\mathrm{ET}} & =\frac{\mathrm{k}_{\mathrm{ET}}\left[\mathrm{O}_{2}\right]}{\mathrm{k}_{\mathrm{ND}}+\mathrm{k}_{\mathrm{L}}+\mathrm{k}_{\mathrm{ET}}\left[\mathrm{O}_{2}\right]}
\end{aligned}
$$

From the luminescence data the second-order rate constant $\left(\mathrm{k}_{\mathrm{ET}}=3.8 \times 10^{8} \mathrm{~L} \mathrm{~mol}^{-1} \mathrm{~s}^{-1}\right)$ and the quantum yield $\left(\varphi_{\mathrm{ET}}=0.57\right)$ for excited state electron transfer from $\left[\mathrm{SnCl}_{3}\right]^{-}$to $\mathrm{O}_{2}$ were obtained.

The quantum yield for the disappearance of $\left[\mathrm{SnCl}_{3}\right]^{-}$is much higher $(\varphi=1.5)$ than that of the primary electron transfer. This discrepancy is caused by secondary processes. Tin(III) [15] and $\mathrm{O}_{2}{ }^{-}$which are initially generated may participate in a variety of subsequent reactions. Furthermore, peroxide, which was identified as a main product in similar photooxidations, appears only in traces in the photolysis of $\left[\mathrm{SnCl}_{3}\right]^{-}$. It is assumed that peroxide does not accumulate because it is consumed in a thermal oxidation of $\left[\mathrm{SnCl}_{3}\right]^{-}$. This re- action would also account for the observation that the photooxidation quantum yield exceeds unity. The final product formation takes place according the overall stoichiometry:

$$
\begin{aligned}
& {\left[\mathrm{SnCl}_{3}\right]^{-}+1 / 2 \mathrm{O}_{2}+n \mathrm{CH}_{3} \mathrm{CN} \stackrel{\mathrm{h} v}{\longrightarrow}} \\
& \mathrm{SnOCl}_{2}\left(\mathrm{CH}_{3} \mathrm{CN}\right)_{n}+\mathrm{Cl}^{-}
\end{aligned}
$$

This photooxidation product is not light-sensitive while the related tin(IV) complex $\left[\mathrm{SnCl}_{6}\right]^{2-}$ undergoes an efficient reductive elimination:

$$
\left[\mathrm{SnCl}_{6}\right]^{2-} \stackrel{\mathrm{h} v}{\longrightarrow}\left[\mathrm{SnCl}_{3}\right]^{-}+\mathrm{Cl}_{2}+\mathrm{Cl}^{-}
$$

In analogy to many other $\mathrm{s}^{0}$ complexes this photoreaction is induced by LMCT excitation. The corresponding LMCT absorption appears at $\lambda_{\text {max }}=228 \mathrm{~nm}\left(\varepsilon=13500 \mathrm{~L} \mathrm{~mol}^{-1} \mathrm{~cm}^{-1}\right)$ [16]. The primary step of this photolysis probably consists of a homolytic $\mathrm{Sn}-\mathrm{Cl}$ bond cleavage which generates a tin(III) intermediate [15]. Subsequent reactions lead to the formation of $\left[\mathrm{SnCl}_{3}\right]^{-}$as the final product which undergoes an irreversible photooxidation to tin(IV) in the presence of $\mathrm{O}_{2}$ (see above). The overall photolysis of $\left[\mathrm{SnCl}_{6}\right]^{2-}$ in the presence of oxygen then takes place according to the stoichiometry:

$$
\begin{aligned}
& {\left[\mathrm{SnCl}_{6}\right]^{2-}+1 / 2 \mathrm{O}_{2}+n \mathrm{CH}_{3} \mathrm{CN} \stackrel{\mathrm{h} v}{\longrightarrow}} \\
& \mathrm{SnOCl}_{2}\left(\mathrm{CH}_{3} \mathrm{CN}\right)_{n}+\mathrm{Cl}_{2}+\mathrm{Cl}^{-}
\end{aligned}
$$

Support of this research by the BMFT (Grant 0329075 A) and the Fonds der Chemischen Industrie is gratefully acknowledged. We thank Dr. Horst Kunkely for emission lifetime measurements.
[1] R. C. Haring, J. H. Walton, J. Phys. Chem. 37, 375 (1933).

[2] a) R. Sard, J. Electrochem. Soc. 117, 864 (1970);

b) J. F. D'Amico, M. A. DeAngelo, J. F. Henrickson, J. T. Kenney, D. J. Sharp, J. Electrochem. Soc. 118, 1695 (1971);

c) J. F. D'Amico, F. A. Litt, M. A. DeAngelo, J. Electrochem. Soc. 119, 956 (1972);

d) M. Paunovic, J. Electrochem. Soc. 127, $441 \mathrm{C}$ (1980).

[3] A. Vogler, A. Paukner, H. Kunkely, Coord. Chem. Rev. 97, 285 (1990).

[4] A. Vogler, A. Paukner, Inorg. Chim. Acta 163, 207 (1989).

[5] A. Vogler, H. Nikol, Pure \& Appl. Chem. 64, 1311 (1992).

[6] A. Becht, A. Vogler, Inorg. Chem. 92, 2835 (1993).

[7] G. W. Parshall, Inorg. Synth. 15, 222 (1974).

[8] P. Day, P. J. Diggle, G. A. Griffiths, J. Chem. Soc. Dalton Trans. 13, 1446 (1974).
[9] J. N. Demas, G. A. Crosby, J. Phys. Chem. 75, 991 (1971).

[10] W. Fresenius, G. Jander (eds); Handbuch der Analytischen Chemie, Vol. VII, a $\beta$, p. 53, Springer, Berlin (1967).

[11] a) H. Fromherz, H. J. Walls, Z. Phys. Chem. A 178, 29 (1936);

b) E. A. Kutner, B. P. Masteevskii, Kinet. Katal. (Engl. Transl.) 10, 997 (1969).

[12] H. Nikol, A. Becht, A. Vogler, Inorg. Chem. 31, 3277 (1992).

[13] C. Franco, J. Olmsted, Talanta 37, 905 (1990).

[14] G. Messin, J. L. Janier-Dubry, Inorg. Nucl. Chem. Lett. 15, 409 (1979).

[15] a) N. Shinohara, K. Mori, M. Inoue, Chem. Lett. 1986, 661;

b) N. Shinohara, M. Inoue, Bull. Chem. Soc. Jpn. 62, 730 (1989).

[16] R. A. Walton, R. W. Matthews, C. K. Jørgensen, Inorg. Chim. Acta 1, 355 (1967). 